This is an electronic reprint of the original article. This reprint may differ from the original in pagination and typographic detail.

Author(s): Fortunati, Leopoldina; Taipale, Sakari

Title: $\quad$ A different glimpse into mobilities : On the interrelations between daily spatial mobility and social mobility

Year: $\quad 2017$

Version:

Please cite the original version:

Fortunati, L., \& Taipale, S. (2017). A different glimpse into mobilities : On the interrelations between daily spatial mobility and social mobility. Information Society, 33(5), 261-270. https://doi.org/10.1080/01972243.2017.1354110

All material supplied via JYX is protected by copyright and other intellectual property rights, and duplication or sale of all or part of any of the repository collections is not permitted, except that material may be duplicated by you for your research use or educational purposes in electronic or print form. You must obtain permission for any other use. Electronic or print copies may not be offered, whether for sale or otherwise to anyone who is not an authorised user. 


\title{
A different glimpse into mobilities: On the interrelations between daily spatial mobility and social mobility
}

\author{
Leopoldina Fortunati \& Sakari Taipale
}

\section{ABSTRACT}

We explore the link between daily spatial mobility and social mobility, taking changes in the contemporary labor market and family as examples. We propose a new theoretical approach to mobility that is defined as a productive force of social labor. Analyzing the relationship between daily spatial mobility and social mobility, we show that spatial mobility has become a strategy of compensation for the lack of social mobility. Explanations for the increase in daily spatial mobility are also provided. Lastly, we reveal how spatial mobility has the capacity to produce major social change, taking the family as an example.

Keywords: Spatial mobility, social mobility, productive force of social labor, mobilities 


\section{Introduction}

Residential mobility has continuously declined in the United States since the late 1940s (Cooke 2013; Fischer 2002; for other countries, see Bell and Charles-Edwards 2013), owing to, among other things, the increase in dual-earning couples and households' indebtedness. By contrast, different forms of short-range spatial mobility such as commuting, as well as long-range spatial mobility such as migration and long travels, have increased. In particular, short-range spatial mobility now constitutes a large and important part of our daily routines (Kellerman 2012a, 2012b). Such mobile lifestyles are seen as a sign of success in contemporary networked societies (Elliot and Urry 2010).

We argue that the meaning of daily spatial mobility can be fully understood only in relation to classical sociological concepts of social mobility (Savage 1988) and social change (Smelser 1963, 1968). Unlike others, we do not focus on individuals and their mobile lifestyles or on mobility infrastructures (e.g., Urry 2000; Elliot and Urry 2010). Instead, we analyze the social meaning of mobilities and the social changes that come with daily two-way mobility. We propose a new theoretical approach wherein spatial mobility is seen as a productive force of social labor. Starting from a reflection on the relationship between short- and long-range spatial mobility and social mobility, we show that spatial mobility compensates for the lack of social mobility. Furthermore, we provide explanations for the increase in daily spatial mobility and we explore how it affects social change. As a large part of daily mobility is either directly related to work or to everyday efforts to reconcile family and work life, we use the current organization of labor and the family as our main examples in this endeavor.

In the following section we position our study in relation to prior mobility research (Cresswell 2011) and present our research questions. The study is, in essence, a theoretical account, which utilizes available statistics and empirical evidence to support main arguments. In the next section, we elaborate on the social meaning of short-range spatial mobilities in the context of the contemporary labor market. Thereafter, we explain why short- and long-range spatial mobility have increased considerably, while residential mobility has been decreasing. Before concluding, we unpack the relationship between daily spatial mobilities and social change, showing the relevance of traditional sociological concepts for mobilities research.

\section{Background}

John Urry (2000) was the first sociologist to pay attention to and systematically study mobilities. He rightly pointed out that traditionally sociologists have focused on the formation of the social within society, including social mobility (vertical and horizontal), but neglected a plethora of other forms of mobility (e.g., physical, imaginary, virtual, and communicative). Although several studies have been conducted on mobilities (e.g., Adey 2010; Kaufmann 2002; Kellerman 2006, 2012a; Urry2000, 2007, 2011a, 2011b), much of this effort has been directed at modeling the structures and dynamics of complex mobility systems. There have also been many ethnographic studies describing the role of mobilities in the daily lives of individuals and communities (e.g., Larsen 2008; Elliot and Urry 2010; Dalakoglou and Harvey 2012). There remains a need for studies that relate everyday mobilities and mobile lifestyles to larger and more established sociological concepts (e.g., social changes, social mobility, and labor).

In fact, some mobility scholars have deliberately distanced themselves, for example, from the analysis of the labor market dynamics and class conflicts, considering it more important to focus on the rates, patterns, and consequences of increased mobility (e.g., Elliot and Urry 2010; Balan, 
Browning, and Jelin 2014). This indifference has been inscribed in the new mobilities paradigm, which underlines the importance of studying "the consequences for social inequality that go beyond that of social class" (Urry 2007, 187). What has driven mobility research is concern about the ecological unsustainability of the current capitalist production systems (e.g., Urry 2011b; 2013).

While ecological concerns are undeniably vital, questions regarding the labor market are also critical. First, the widespread diffusion of information systems has enabled the reorganization of the global economy and labor markets. Consequently, a substantial part of labor has become abstract with the detachment of labor from place and localities where it is exercised. Even though working people do not change their permanent place of residence as often as in the past (Molloy, Smith, and Wozniak 2011; Bell and Charles-Edwards 2013; Fischer 2002), they are kept busy by an array of daily spatial mobilities at both the physical and virtual levels.

Here we find Kellerman's (2012a) distinction between daily and nondaily spatial mobility useful. In contrast to one-way mobilities, such as change of residence or migration, which are rather fundamental and often entail social change, repeatedly performed two-way mobility such as commuting constitutes a large and important part of our daily life (Kellerman 2012a). Kellerman further divides daily spatial mobilities into corporeal and virtual mobilities (Kellerman 2012a), which are fueled by three intrinsic "push" factors (locomotion, proximity, and curiosity) and several external "pull" factors (employment, shopping, entertainment) (Kellerman 2012b).

While the relationship between daily spatial mobility, especially in relation to labor markets, and social mobility calls for more attention, scholars like Kaufman and M ontulet $(2008,49)$ have questioned the relationship between the two, arguing that "spatial mobility and social fluidity are two aspects of the reality which do not necessarily go hand in hand. Social mobility is a metaphor of spatial mobility; the dimension that rules them cannot simply be put on a par. ${ }^{1}$ Other scholars admit that social and daily spatial mobilities may potentially interrelate. Upward social mobility may relate to wider and more intensive spatial mobility, and vice versa (Kellerman 2012a), although these relations are repeatedly portrayed as complex (Adey 2010; Kellerman 2012a; Urry 2007). We posit that this emphasis on complexity and mingling of the concrete physical mobility with the metaphoric expression of social mobility has not resulted-nor will it result-in a proper analysis of the interrelations between daily spatial mobility and social mobility. This relationship needs to be systematically analyzed and theoretically understood. To provide foundation for a sociological debate on the interrelations between daily spatial mobility and social mobility, we pursue the following three questions as guides for our analysis:

- What is the social meaning of daily spatial mobility (especially commuting) and social mobility in the context of the labor market?

- Why has daily spatial mobility increased so much?

- What is the relationship between daily spatial mobility and social change?

\section{The social meaning of daily spatial mobility and social mobility in the context of the labor market}

Notions such as spatial mobility and social mobility are often described, discussed, and investigated but rarely explored in terms of a critique informed by political economy. Drawing on Marx (1964: Capital, Vol. I), we propose here that the ultimate social meaning of daily spatial mobility, in regard to the labor market, is its role as a productive force of social labor, which contributes greatly to 
valorization of capital. Specifically, M arx identifies as productive forces social labor cooperation and division of labor, as, he argues, they make the labor more productive. M arx also characterizes them as natural forces because they do not cost anything to capital. In our view, mobility is another productive force of social labor because it makes the workers available where they are needed. To capital, workers' availability does not cost anything but it enables the production process. Since mobility does not cost anything to capital mobility, it can also be characterized as a natural force of social labor. Although mobility incorporates objectified labor, it is treated as a natural force of social labor. As such, it is incorporated almost without cost inside production as an agent of the production process.

As with other productive forces, the value of mobility is transferred in the capital production process from labor to capital (Marx 1965b, 940). On the one hand, workers on the move are commodities of the transportation industry. On the other hand, for their employers they are commodities in the circulation phase (M arx 1965a, 305). The value produced by the means of transportation is incorporated in individual consumption (M arx 1965a, 163). But as Fortunati (1981) points out, individual consumption enables labor's participation in production and therefore should be included in the production process. From this viewpoint, mobility valorizes capital on two levels: indirectly within the reproductive sphere, where labor is sustained and reproduced as a resource for the production process, and directly in the production sphere. Conversely, it also devalorizes labor. M obility as a natural force of social labor has meant the prolonging of the working day for millions of workers.

Let us consider examples of how mobility has devalorized workers. Commuting time has increased in many developed countries at least from the 1970s to 2000s. In Germany, the increase between 1991 and 2011 was 8 minutes per day; in the Netherlands, 3 minutes between 1975 and 2000; and in the United States, 12 minutes between 1975 and 1994 (Gimenez-Nadal and M olina 2014). In Italy, the number of commuters increased by 1 million from 2007 to 2012, representing 23\% of the entire population over 14 years old (CENSIS 2012). The majority of commuting takes place at the local level in Italy, where the distance traveled averages $24 \mathrm{~km}$ and each journey takes 43 minutes on average. Commuters "worked by commuting" more than 6 weeks per year, as they spent an average of 72 minutes on the daily commuting round trip, or 33 working days per year. In their daily commutes $70 \%$ of commuters, especially workers, used public transport, and the monthly expenditure borne by commuters was on average 45.30 Euros for those using bus services, 49.20 Euros for those using trains, and 109.50 Euros per month on fuel alone for those using cars (CENSIS 2008). In many countries, men spend more time on commuting than women, with considerable variations between countries. Interestingly, having children adds to the time men spend on traveling between home and work in several countries, while the opposite is typically true for women (Organization for Economic Cooperation and Development [OECD] 2016). The costs of this mobility are borne by workers in terms of money and "wasted" time.

Commuters live in the "middle lands," as the ancient Greeks called the uninhabited territories that separated the civilized world from the barbarians. Commuting causes the loss of regular face-to-face contact and social relationships with friends, comrades, classmates, and parents. From this perspective, commuting has the negative effect of emptying sociability from the inside. The maintenance of sociability requires staying in one place and continuity in one's spatial coexistence. When continuity is interrupted, so ciability is harmed.

If we look at the past, we find that the capitalist system has always necessitated the mobility of the workforce. With industrialization, the ruling class needed peasantsto become its workforce and forced them to move from the countryside to factories (M arx 1964). This push for the mobility of 
workers has never been as strong as it is today. On the other hand, the diversification of mobility has allowed two-way regular mobility between the home and work, instead of permanent residential changes. A study from the United Kingdom, for example, reveals that commuters choose longer weekly (staying away the entire week from M onday to Friday) journeys between home and work because they may offer substantial career and financial benefits (Green, Hogarth, and Shackleton 1999).

Today, workers are not only pushed to move on a daily or weekly basis by employers but also by governments that implement labor-market policies that often presume commuting (LudwigMayerhofer and Behrend 2014). In consequence, for a larger share of workers it is no longer sufficient to sell only their work capacity; they also have to sell their capacity to move. Most of this mobility is commuting that occurs at a local or regional level. M oreover, a significant number of workers, managers, and professionals also regularly commute between two countries on the same or even on different continents (see analysis of "globals," in Elliot and Urry 2010). This capacity to move that is now required of workers is the outcome of two different and often conflicting behaviors-one of entrepreneurs and the other of workers.

First, after World War II a significant change occurred in the housing strategies of families when much of the workforce, due to a large wave of urbanization, moved to cities. As a result, many young people abandoned the villages, escaping the control of their extended families. While a part of the extended family remained in the villages, another part moved to the cities. This historical change in family context led to new forms of mobility. New technologies like the telephone and the car were adopted to maintain social ties and a sense of belonging with distant relatives on a daily basis (about studies on visiting friends and relatives see, e.g., Backer 2007; M olloy, Smith, and Wozniak 2014). More recently, those already living in the urban areas began to look for lower cost accommodation or more space. In particular, young families with children started to move from urban centers to the suburbs and even to the countryside, further away from their workplaces. These displacements led to new requirements to commute and travel on a regular basis.

Second, the entrepreneurs also looked for the best location for their businesses and for improved logistics. With the availability of information technology (IT)- enabled connectivity, businesses started to migrate to thecountryside. In consequence, cities were transformed and city centers progressively became the preserve of banks and other financial institutions and international retail chains (Archer 2013; Law 1993; Fischer 2002). The small shops could no longer afford the rents and they remain with no other choice than to close down (Cavallo, Komossa, and M arzot 2014).

These two conflicting behaviors create a social irrationality that affects the productive and harmonious functioning of social systems. The more cities grow, the more the choices for housing and businesses change, and the increased time spent on commuting adds to the incompatibility of time rationalities of the various sectors: business/work, family life, public services, and others. Although political measures have been taken to reorganize time schedules such as those directed at bringing about greater equitability in participation of men and women in paid work and the political process, their success has been limited (Perrons et al. 2006). The indifference to this social irrationality in the temporal and spatial orders of the city is probably due to the fact that a large part of daily mobilities pertains to the sphere of family and social reproduction (see Green, Hogarth, and Shackleton 1999). Thus, the social costs of this irrationality are borne by workers and their families, not employers or society, in terms of wasted time and money.

We argue that spatial mobility has been vaguely perceived and incompletely treated from this particular point of view: We need to understand what daily spatial mobility means in respect to the 
economic system and the organization of labor markets, which are key areas of sociological interest. More clarification can be found in the critics informed by political economy, who suggest that mobility is a natural force of unpaid, so-called social labor. M arx $(1964,375)$ had already noted that the productive forces of capital are owned by capital as immanent productive forces. They do not cost capital anything but they greatly increase its valorization.

\section{The increase in daily short- and long-range spatial mobility}

The second shortcoming of the current literature we address is the lack of understanding of why short- and long-range daily spatial mobility have increased so much. In this section, we offer our answer by showing that it is the "stability" of social mobility in contemporary societies that has entailed, in a compensatory logic, the growth of daily short- and long-range spatial mobility. The vivifying capacity of spatial mobility has served to moderate frustrations from lack of social mobility.

In social phenomenology (Sorokin 1927), the distinction between vertical and horizontal mobility is important. Horizontal mobility takes place within the same social stratum and generally represents both the dynamic strength of the labor market and the rigidity of the marriage market, which usually tends to reaffirm the class position of spouses. Vertical mobility entails shift of an individual (or a group) from one social stratum to another, which can be superior (upward social mobility) or inferior (downward social mobility).

For many reasons, upward mobility is particularly important for the capitalist system. It justifies the ideology of capitalist societies by showing that each individual with talent and good fortune can succeed in moving to a superior position from that of birth. In fact, when the regulating mechanisms are not capable of selecting the best human resources for the highest positions, this tends to have depressive effects on society. On the other hand, capital does not refrain from diminishing the middle and high classes when needed. In other words, capital can also induce downward social mobility. For instance, global capital has concentrated its accumulation dramatically (Hardt and Negri 2000). This has generated upward mobility in countries with cheap labor, most notably the rise of middle class in China and India, and downward mobility in countries with expensive labor, most notably the decline of the middle class in the United States.

According to studies by Pareto (1988) on the circulation of elites and by Gini (1930) on demographic metabolism, there is a concrete but limited need for vertical mobility because ruling classes, being less prolific than middle and lower classes, increasingly reduce their numbers and hence need to be revitalized from the bottom. Pareto (1988) argues that it is important to consider the speed of elite circulation in relation to the overall supply and demand of certain work and professions, as this influences the social equilibrium. Recognizing the changing links between certain ruling classes, which rise and fall over time, and capital, Pareto argues that history is a "cemetery of aristocracies" (Pareto 1988) because over time ruling classes decay as they lose energy and other elements that had enabled them to obtain and retain their power.

Empirical studies on professional mobility and, in particular vertical social mobility, point toward the rigidity of social mobility. Women's social mobility has traditionally been more limited than men's (Payne and Abbott 2005). Education, although typically seen as a vehicle for reducing inheritance of social positions over generations, today does not guarantee such mobility (Breen and Luijkx 2004; cf. Breen 2010). Others have also argued that the influence of father's class status on children's educational choices may hamper intergenerational social mobility (Van de Werfhorst and Luijkx 2010). This is in contrast to baby boomers, for whom economic development and industrialization, 
together with the development of mass education systems and growth in skilled nonmanual occupations, opened opportunities for upward social mobility. In the last few decades, however, overall mobility changes have remained largely unaltered (Scott and M arshall 2005). Since the 1980s, we have also witnessed the weakening of the capacity of political parties, unions, and movements to challenge the inertia produced by entrenched social structures. Dissatisfaction with politics and lack of willingness to engage in the political sphere allowed the statusquo to prevail.

The situation with regard to social mobility is pretty much the same across advanced countries. In the mid 1980s, Goldthorpe demonstrated "a pattern of 'trendless fluctuation' rather than showing evidence of a general increase. In short, therefore, there is no long-term 'loosening' of the class structure, no increase in 'fluidity', and (by implication) no move towards meritocracy" (quoted in Scott and Marshall 2005, 419). A more recent study shows that there has been a growing similarity between countries with regard to their class structure and rates of absolute mobility (Breen 2004).

Moreover, many people, including baby boomers, have recently experienced a new kind of downward mobility. Large social investment in labor during the post-World War II economic boom was motivated by parents' desire to give their children a better life than they had, beginning with a better education. However, for the younger generations (especially highly educated youth) from the 1970s onward, globalization and the deployment of information systems led to high levels of unemployment. This new wave of proletarization and the severe economic crisis of the 2000s have shaken the power relationships among the traditional social classes. Bearing all this in mind, we argue that daily short- and medium-range spatial mobility has been a powerful expedient that has helped people cope with this process of pauperization (see, e.g., Ederveen, Nahuis, and Parikh 2007). If I cannot improve where I am, I move to gain a better life.

From this, it should be clear why a society for which the social structures have been resistant to substantial changes has become very mobile spatially. At the level of social structures, the increase in spatial mobility has been due to a reaction against the sense of stagnation brought about by rigid social mobility. The increased spatial mobility shows an outburst of vitality when the opportunity for upward social mobility is diminished and life has become more impersonal due to commodification. Hence, we argue that the increased daily spatial mobility denotes the intensification of life.

Second, at the psychological level, the expansion of spatial mobility is connected to the transformation of the self with modernity. We return to Simmel, who in 1900 acutely observed:

The lack of something definite at the center of the soul impels us to search for the ... momentary satisfaction in ever-new stimulations, sensations and external activities. Thus it is that we become entangled in the insatiability and helplessness that manifests itself as the tumult of the metropolis, as the mania for traveling, as the wild pursuit of competition, and as the typical modern disloyalty with regard to taste, style, opinions and personal relations.(Simmel 2014, 529)

Simmel points to the fragility of the psychologically stable center of the self in modernity. It is the alienation of modern life that makes people nervous, and thus unstable in their attitudes and behaviors. In this sense, the increased geographical mobility seems to have accentuated the fragility of the self that has become increasingly uprooted from a space tied to temporal continuity.

The third explanation for the increase in daily spatial mobility is related to the level of subjectivity. As a grassroots reaction against rigid social immobility (and decreased residential mobility), people 
travel for leisure more than ever before. According to the World Tourism Barometer, in 2013 the number of international tourists in the world reached 1.087 billion (World Tourism Organization [UNWTO] 2014), almost doubling the number in 1995 (529 million). With the mainstreaming of tourism, people started to travel more frequently for amusement, interaction, and sightseeing, as well as to increase knowledge and understanding, and just to be elsewhere.

The increase in spatial mobility has represented a great step forward in expanding the mind, observing other ways of life, and experiencing other mentalities and languages. Sedentariness, on the other hand, means the acceptance of the separation from others and rooting in a well-known place, family, and tradition. Spatial mobility also entails a considerable change in the sense that it makes people less parochial by exposing them to the wider world. In fact, such mobility challenges the stability of relationships and leads to less frequent communication, which can also reinvigorate couples and vivify life. But since relationships have to straddle distance due to mobility (regarding intimate relations at a distance, see Elliot and Urry 2010), they necessitate more energy and effort for their maintenance. In sum, the increase in daily spatial mobility can be seen at the individual sociopsychological level as a response to diminished social mobility. In terms of political economy, this reaction should be read as a political and social initiative through which multitudes have sought to enrich their lives.

\section{The relationship between spatial mobility and social change}

Generally, social change refers to any variation in the ownership, state, or structure of the social organization of a given society (for the classical theories on social change see, e.g., Comte 1896; Spencer [1876-1896] 1925-1929; Ogburn 1922; Smelser 1959). In this section we limit our analysis to one microsocial structure: family. Given the resistance to change in social mobility, we said, people have started "moving" to animate and improve their lives. But what has been the consequence of this moving around?

We rely here on Gallino (1993), who distinguishes between endogenous and exogenous social changes. He argues that the most recognized endogenous social changes are (1) the increase of the dimensions of the system; (2) the conflict between groups and social classes, which influences the distribution of resources and the motivation to act on the political level; (3) capital accumulation, which influences the formation of new social strata or classes, the labor market, and the forms of political dominion; (4) collective behaviors such as social movements, which express fundamental changes in needs, desires, values, and attitudes of the masses; and (5) the confluence of particular social personalities and emotions that are incompatible with the existent social structures (stressed also by Pareto 1988). Among the exogenous factors Gallino (1993) mentions are wars; major changes in population; changes in the natural environment (earthquakes, drought, etc.); development of technology and science; norms of law; contact between cultures through migration, tourism, mass media, and others; exceptional personalities and innovators; and diffusion of new social values. Of course, none of these factors alone can explain the transformations in our society. We know that social changes are products of complex interactions among multiple factors.

In order to understand the social change produced by mobility, we pay attention here to familyrelated mobility. Not least because of the increase in dual-earner families in many countries, over the last few decades the family has been put in motion: Newborns go to the nursery; children to the kindergarten; older youth travel to schools, universities, and workplaces. Women go to work, enjoy social life, and participate in the public sphere (Polletta and Chen 2013). Older adults and the elderly 
move to express a more or less "active" lifestyle - traveling for family visits, health care, socializing, and tourism. And the more sedentary individuals even become somehow virtually mobile by observing the increased movement around them (Urry 2000).

Diversification of family types and the change in life cycle have also contributed to increased spatial mobility. For example, single-parent and recombined families often lead to an increase in the children's commute to the house of the other parent. One-person households also register more mobility in order to gain a certain level of sociability, which is necessarily outside the home.

Although the increased mobility of family members has not translated in reality into a higher level of sociability (Fortunati, Taipale, and de Luca 2013), certainly the lifestyle of different members of the family has become more independent. Greater autonomy has led to greater isolation at the family level, and has added to mobility as each member moves by him-/herself (Kennedy and Wellman 2007; Kuman and M akarova 2013). The time family members physically live together has become more limited over the overall life cycle, as people spend longer periods of time alone (e.g., when they study, when they break their romantic relationship, after they divorce, or when they are old). Correspondingly, spatial mobility has been also increased. Furthermore, the number of people who choose or are forced by events to live alone has grown and is expected to grow even more in the future (OECD 2011). In effect, when we are a family, we live less together and more alone.

Family members are differently situated in the world of increased mobility. Some, for example, have earned a greater degree of mobility while others have less (see, e.g., Holdsworth 2013). Adults have acquired greater freedom for mobility compared to children and teenagers. They are able to move more easily and to greater distances, while children have less freedom to move about and explore places-increased complexity of cities and safety issues make parents cautious (Boyd 2014). Women, like the elderly, have also earned more mobility, reducing the gap in comparison to men (Law 1999).

Another mode of mobility that has affected families is media (see "imaginative mobility" in Büscher and Urry 2009; Larsen, Urry, and Axhausen 2006; Urry 2007). Media have brought the world inside the house, permeating the domestic sphere with the rhythms of the outside world. News presents a world in continuous change, and this has trained people to pay attention to and be more prepared to deal with the changes in their own everyday life. Furthermore, visual narrativity (in movies, series,etc.) has broadcast the representation of societies, especially in America, where social bonds are less strong and less rooted in tradition. Later, the spread of the computer and the Internet in the 1990s strengthened this influence and also encouraged mobility. Suddenly, the world became familiar and ready to be reached.

Imaginative mobility, which from a communication perspective can be called "secondary mobility," $s$ mediated by information and communication technology (ICT; Fortunati and Taipale 2017). It has a different emotional valence than physical or "primary" mobility. For example, thanks to new ICT we are probably less anxious while traveling as we can gain all kinds of information about routes and destinations prior to the journey.Approaching mobility from this standpoint makes us think that mobile media have not drastically reduced spatial mobility, as was expected at the start of their diffusion (Palen, Salzman, and Youngs 2001). But more recent research suggests that the situation is much more complex (Taipale 2014).

There are several changes produced at the social level by family mobility. First, family mobility has strengthened the development of individualization, one of the defining processes of contemporary societies. Second, it has proved to be a powerful means of both separation from and unification with others (Holdsworth 2013). It has enhanced the ability to break away from the regular habits that 
numb energy and to bring in new energies.Third, more people have gained a stronger capacity to master the territory around them and that has fueled civil rights movements. Fourth, family mobility has loosened the hold of roots, habits, and stereotypes.

From this analysis, it is clear that various modes of daily spatial mobility, both corporeal and virtual, are both endogenous and exogenous factors of social change. They are endogenous since they are the fruit of collective behaviors and exogenous because they are connected to external forces. But how have they been activated? The multitudes have decided to discover the world, to react against what working-class organizations never succeeded in doing, which is constructing a truly international large network of like-minded people. Spatial mobility has had the effect of developing contacts among cultures, opening the mind, and allowing individuals to experience different lifestyles. The same will has been expressed by multitudes through the adoption, reinvention, and use of ICT. Spatial mobility and the use of ICT represent a mass desire of people to move in order to open up a new path inside the dynamics of power and empowerment, prompted by their exposure to the widerworld.

In sum, mobility has given rise social changes within the family, which are both progressive and regressive. They are progressive because they stimulate people's empowerment and the development of the overall society. However, they also contain elements of regression because they interject commodification, control, and power into the everyday life of people. Based on the preceding, it is fair to argue that that these social changes engendered by daily spatial mobility are both long-term and large-scale.

\section{Conclusions}

In this article, we analyzed the relationship between social mobility and geographical mobility, showing how they are structurally intertwined and how one is needed to understand the other. To do so, we firstly scrutinized the structural functions of mobility and its social meaning in the framework of political economy. Drawing upon critiques informed by political economy, we proposed a new conceptualization of mobility as a productive force of social labor and thus as a powerful vector of capital valorization. This new conceptualization brought us to refine the Marxian notion of abstract labor, which nowadays entails the detachment of labor from place and localities. To answer our first research question, we focused on a particular form of the spatial mobility as productive force of social labor that stems from the separation of work and family-commuting (Aldred 2014). We found that different rationales-use of mobility as a productive force of social labor and the use of mobility to empower oneself-apply to spatial choices affecting housing and work, and they are often in conflict. However,both of them dovetail in the changing of the social order insidiously from the bottom up. Our examination of relationship between the current stability of social mobility and increase in spatial mobility suggests that mobility offers the possibility of fighting against a sense of stagnation, to vivify life and make it more meaningful and adventurous, and to experience new cultures. In summary, daily spatial mobility has become a strategy of compensating for overly rigid and stable societies, in order to reinstate some degree of movement and change.

Second, we sought to understand why spatial mobility has increased so much. Here travel by the labor force was used as an example. At the level of the structures of society, we argued that upward social mobility ensured, for a long time, the social dynamics that legitimated the capitalist system itself. When the regulating mechanisms of societies are no longer able to provide better social 
positions for talented workers, the fixity of social (class) structures begins to have depressive effects for a society. At the psychological level, we argued that the increase in geographical mobility relates to the intensification of life on the one hand, and to the increasing erosion of the self, which impels the individual's never-ending quest for new stimulations, sensations, and activities-all well provided by travel. At the level of subjectivity, we proposed that increase in mobility is an expression of grass-roots reaction against immobility. M obility not only provides experience, knowledge, and hope; it also restores the sense of proximity and unity with people and creates a sense of internationality, which working-class organizations have never really been able to provide.

Third, we examined the relationship between geographical mobility and social change. This was carried out by analyzing more carefully the relationship between frequent spatial mobility and social change, and in connection with one of the basic units of society: the family. At the micro level, we argued that family mobility has furthered individualization, and has become a powerful means of both separation from and reconnection to others. All the members of a family now have increased mobility, and with that, families have a greater presence in public places than in the past (Kumar and Makarova 2013). Even those who do not travel or commute have become more mobile. This is a mixed blessing: On the one hand, family mobility has increased by necessity-the need to go to work and schools. On the other hand, family mobility has been long wanted by women, the elderly, and youth. To them, this has meant more degrees of freedom and mastery of space.

With this study we have demonstrated the significance of geographical mobility as a sociological concernin a new sense, by analyzing social mobility from the perspective of political economy. ${ }^{2}$ This study implies that more scholarly efforts are required to understand the structures of mobilities in the light of traditional sociological theories. A proper program for future research needs to be outlined. First, more efforts are needed to identify all the social consequences that develop from the geographical mobility as a productive force of social labor within the current capitalist system. Second, surveys on commuting should be developed and carried out in European countries and beyond, to understand the dynamics propelling workrelated travelling.

Third, psychosociological reflections and qualitative research are required to gain more knowledge about the effects of commuting in the daily lives of commuters. Fourth, while we posited one possible interpretation for the social function of the increased geographical mobility-mobility as a reaction to the lack of social mobility-there might be other explanations that are worth investigating. Fifth, a retrospective historical analysis of people's reactions to the increased commuting, family mobility, and related struggles, as part of their personal history, would shed new light to the political economy of geographical mobility. This is particularly important as in many countries there are no unions to defend the interests of workers as commuters. Finally, while we discussed the relationship between mobility and social change in connection to the family, it must be argued that many other domains are also affected by this relation and hence deserve similar attention.

\section{Endnotes}

1. Social mobility is considered a metaphor of spatial mobility as it also entails a movement-upward or downward movement between tiers in the social stratification system of a society.

2. Nevertheless, the current volume of spatial mobility may only be a short moment in human history (Urry, 2011a, xvii), because several factors, such as climate change, pollution and oil shortage, will present serious constraints to the maintenance of high levels of mobility. Work and 
societal lives have to be reconfigured to "avoid a 'societal collapse' through internal contradictions" (Urry 2011a, xvii).

\section{Acknowledgments}

An early version of this study was presented at the International Research Workshop "M obile Communication. M obile Internet, Locative Media, Mobility and Place," held in Aarhus,Denmark, March 29-30, 2012. This research is also connected to the "Networked Individuals Project" supported by the Social Sciences and Humanities Research Council of Canada, 2015-2018.

\section{References}

Adey, P. 2010. Mobility. London, UK: Routledge.

Aldred, R. 2014. To commute. In The Routledge handbook of mobilities, ed. P. Adey, D. Bissel, K. Hannam, et al., 450-59. London, UK: Routledge.

Archer, K. 2013. The City: The Basics. London: Routledge.

Backer, E. 2007. VFR travel: An examination of the expenditures of VFR travellers and their hosts. Current Issues in Tourism 10 (4):366-77.

Balan, J., H. L. Browning, and E. Jelin. 2014. Men in a developing society: Geographic and social mobility in M onterrey,M exico. Austin, TX: University of Texas Press.

Bell, M., and E. Charles-Edwards. 2013. Cross-National Comparisons of Internal Migration: An Update on Global Patterns and Trends. New York: United Nations.

Boyd, D. 2014. It's complicated: The social lives of networked teens. New Haven, CT: Yale University Press.

Breen, R. 2010. Educational expansion and social mobility in the 20th century. Social Forces 89 (2):365-88.

Breen, R., ed. 2004. Social mobility in Europe. Oxford, UK: Oxford University Press.

Breen, R., and R. Luijkx. 2004. Conclusions. In Social mobility in Europe, ed. R. Breen, 383-410. Oxford, UK: Oxford University Press.

Büscher, M., and J. Urry. 2009. Mobile methods and the empirical. European Journal of Social Theory $12(1): 99-116$.

Cavallo, R., S. Komossa, and N. Marzot (eds). 2014. New urbanc onfigurations. Amsterdam, The Netherlands: IOS Press.

CENSIS. 2008. Pendolari d'Italia. http:// www.censis.it/7?shadow_comunicato_stampa D 5540 (accessed August 27, 2014).

CENSIS. 2012. Rapporto M unicipium 2012. http:// www.anci.it/index.cfm?layout D dettaglio\&IdDett D 40001 (accessedAugust 27, 2014). 
Comte, A. 1896. The positive philosophy of Auguste Comte,Vols. 1, 2, and 3, trans. from French and condensed by H.Martineau. London, UK: George Bell.

Cooke, T. 2013. Internal M igration in Decline. The Professional Geographer 65 (4):664-675.

Cresswell, T. 2011. M obilities I: Catching up. Progress in Human Geography 35 (4):550-58.

Dalakoglou, D., and P. Harvey. 2012. Roads and anthropology: Ethnographic perspectives on space, time and (im)mobility. M obilities 7 (4):459-65.

Ederveen, S., R. Nahuis, and A. Parikh. 2007. Labour mobility and regional disparities: The role of female labour participation. Journal of Population Economics 20 (4):895-913.

Elliot, A., and J. Urry. 2010. M obile lives. London, UK:Routledge.

Fischer, C. S. 2002. Ever-M ore Rooted Americans. City and Community 1 (2):177-198.

Fortunati, L. 1981. L'arcano della riproduzione. Casalinghe, prostitute, operaie e capitale. Venezia, Italy: M arsilio. (English trans. The arcane of reproduction: housework, prostitution, labor and capital. New York, NY: Autonomedia, 1995).

Fortunati, L., S. Taipale, and F. De Luca. 2013. What did happen to body-to-body sociability?. Social Science Research 42 (3):893-905.

Fortunati, L., and S. Taipale. 2017. M obilities and the network of personal technologies: Refining the understanding of mobility structure. Telematics \& Informatics 34 (2):560-68.

Gallino, L. 1993. Dizionario di Sociologia. Turin, Italy: UTET.

Gimenez-Nadal, J. I., and J. A. M olina. 2014. Commuting Time and Labour Supply in the Netherlands: A Time Use Study. Journal of Transport Economics and Policy 48 (3):409-426.

Gini, C. 1930. Nascita, Evoluzione e morte delle nazioni. Rome, Italy: Libreria del littorio.

Green, A. E., T. Hogarth, and R. E. Shackleton. 1999. Longer Distance Commuting as a Substitute for Migration in Britain: A Review of Trends, Issues and Implications. International Journal of Population Geography 5 (1):49-67.

Hardt, M ., and A. Negri. 2000. Empire. Cambridge, M A: Harvard University Press.

Holdsworth, C. 2013. Family and intimate mobilities. Basingstoke, UK: Palgrave.

Kaufmann, V. 2002. Re-Thinking mobility: Contemporary sociology. Aldershot, UK: Ashgate.

Kaufmann, V., and B. Montulet. 2008. Between Social and Spatial M obilities: The Issues of Social Fluidity. In Tracing M obilities: Towards a Cosmopolitan Perspective, ed. W. Canzler, V. Kaufmann, and S. Kesselring, 37-56. Aldershot: Ashgate.

Kennedy, T. L., and B. Wellman. 2007. The networked household. Information, Communication \& Society 10 (5):645-70.

Kellerman, A. 2006. Personal mobilities. London, UK: Routledge.

Kellerman, A. 2012a. Daily spatial mobilities. Farnham, UK: Ashgate.

Kellerman, A. 2012b. Potential Mobilities. M obilities 7 (1): 171-183. 
Kumar, K., and E. M akarova. 2013. The portable home: The domestication of public space. Sociological Theory 26 (4):324- 43.

Larsen, J., J. Urry, and K. Axhausen. 2006. M obilities, networks, geographies. Farnham, UK: Ashgate. Larsen, J. 2008. Practices and flows of digital photography: An ethnographic framework. M obilities 3 (1):141-60.

Law, C. M. 1993. Urban Tourism: Attracting Visitors to Large Cities. London: M ansell.

Law, R. 1999. Beyond 'women and transport': Towards new geographies of gender and daily mobility. Progress in Human Geography 23 (4):567-88.

Ludwig-M ayerhofer, W., and O. Behrend. 2014. Enforcing mobility: Spatial mobility under the regime of activation. Mobilities 10 (2):326-343.

Marx, K. 1964. II Capitale [Capital], Vol. I. Rome: Editori Riuniti.

Marx, K. 1965a. Il Capitale [Capital], Vol. II. Rome: Editori Riuniti.

Marx, K. 1965b. II Capitale [Capital], Vol. III. Rome: Editori Riuniti.

Molloy, R. S., C. L. Smith, and A. K. Wozniak. 2011. Internal Migration in the United States. Journal of Economic Perspectives 25 (3):173-196.

Molloy, R. S., C. L. Smith, and A. K. Wozniak. 2014. Declining Migration within the US: The Role of the Labor Market. Bonn: Institute for the Study of Labor (IZA).

OECD. 2016. Time Spent Travelling to and from Work.

https:// www.oecd.org/ els/ family/ 43199696.pdf (accessed June 8, 2016).

Ogburn, W. F. 1922. Social change with respect to culture and original nature. New York, NY: B. W. Huebsch.

Organization for Economic Cooperation and Development. 2011. The future of families to 2030. A synthesis report. www.oecd.org/ futures/ 49093502.pdf (accessed June 3, 2017).

Palen, L., M. Salzman, and E. Youngs. 2001. Discovery and integration of mobile communications in everyday life. Personal and Ubiquitous Computing 5 (2):109-22.

Pareto, V. 1988. Trattato di sociologia generale, Vol. 4. Turin, Italy: UTET.

Payne, G., and P. Abbott (eds.). 2005. The social mobility of Women: Beyond male mobility models. Basingstoke, UK: Taylor \& Francis.

Perrons, D., C. Fagan, L. M cDowell, K. Ray, and K. Ward, eds. 2006. Gender divisions and working time in the new economy. Changing patterns of work, care and public policy in Europe and North America. Cheltenham, UK: Edward Elgar.

Polletta, F., and P. C. B. Chen. 2013. Gender and public talk: Accounting for women's variable participation in the public sphere. Sociological Theory 31 (4):291-317.

Savage, M. 1988. The missing link? The relationship between spatial mobility and social mobility. British Journal of Sociology 39 (4):554- 77.

Scott, J., and G. Marshall (eds). 2005. Oxford dictionary of sociology. Oxford, UK: Oxford University Press. 
Simmel, G. 2014. Philosophy of money, trans. from German by T. Bottomore and D. Friby. New York, NY: Routledge.

Smelser, N. J. 1959. Social change in the industrial revolution: An application of theory to the British cotton industry 1770-1840. London, UK: Routledge and Kegan Paul.

Smelser, N. J. 1963. Theory of collective behavior. New York, NY: Free Press.

Smelser, N. J. 1968. Essays in sociological explanation. Englewoods Cliffs, NJ: Prentice Hall.

Sorokin, P. A. 1927. Social mobility. New York, NY: Harper \& Brothers.

Spencer, H. [1876-1896] 1925-1929. The principles of sociology, 3 vols. New York, NY: Appleton.-

Taipale, S. 2014. The dimensions of mobilities: The spatial relationships between corporeal and digital mobilities. Social Science Research 43C:157-67.

World Tourism Organization. 2014. World tourism barometer. 12.

dtxtq4w60xqpw.cloudfront.net/sites/all/files/pdf/unwto_barom14_01_jan_excerpt.pdf (accessed August 27, 2014).

Urry, J. 2000. Sociology beyond societies. M obilities for the twenty-first century. London, UK: Routledge.

Urry, J. 2007. Mobilities. Cambridge, UK: Polity.

Urry, J. 2011a. Foreword. In The politics of proximity. M obility and immobility in practice, ed. G.

Pellegrino, XV-VII. Farnham, UK: Ashgate.

Urry, J. 2011b. Climate change and society. Cambridge, UK:Polity.

Urry, J. 2013. Societies beyond oil. London, UK: Zed.

Van de Werfhorst, H. G., and R. Luijkx. 2010. Educational field of study and social mobility: disaggregating social origin and education. Sociology 44 (4):695-715. 